\title{
THE NARRATIVE CHARACTERISTICS OF ISLAMIC TERRORISM DISCOURSES
}

\author{
Ridwan Rosdiawan \\ Pontianak State Institute of Islamic Studies
}

\begin{abstract}
While polemics is still shadowing the internationally accepted definition, the word "Terrorism" becomes more controversial when it is paralleled with "Islam". The Islamic Terrorism discourse is more likely to be an elusive concept if not a Fata Morgana. Its very existence appears as a real entity but its form can hardly be described. It would be always be problematic to posterize such a terrible notion as "terrorism" and put it side by side with a noble concept as in "Islam". The fact, however, shows that the two-word has been widely discussed in global arena. "Islamic Terrorism" has become a trending topic in global politics and academic discourses in the first decade of the millennium.
\end{abstract}

Keywords: Terrorism, Islam, Discourses

\section{INTRODUCTION}

The widely-held discussions on terrorism in the wake of the September 11, 2001 event in the United States have almost certainly touched the debate on Islam and/or at least Muslims. This is highly ironic. Terrorism which means violent acts with a political goal carried out by creating a terrifying situation is labeled on Islam, a religion which literally means gentleness, submission, and leading to the purpose of the peace of the world and life afterwards. This irony also continues as the word 'Islamic terrorism' is repeatedly mentioned but merely refers to a common sense where there is no definite definition that describes its specifications. Assumptions that arise and become a description when the term 'Islamic terrorism' is used generally to refer to a concept as defined by Wikipedia as follows: "a form of religious terrorism committed by extremists of Islam mostly for the religious beliefs and sometimes on achieving varying political ends again in the name of religion"

Violence with religious motives are in fact not something new and certainly not exclusively practiced by adherents of a particular religion. History has recorded a long documentation of violence against other groups on the basis of conviction. However, which actions are regarded as terrorism and which are notisabigproblembecausetheyhavepoliticalconsequencesandhaveimplications 
for moral rhetoric. Northern Ireland Liberation Army (IRA) viewed their Group as doing sacred religious struggle against the domination of the British rule in the territory. Timothy Mc Veigh did not feel sorry at all as he brought down the FBI building with hundreds of people killed inside because he looked at the action as a struggle to stop the 'formal' government oppression against a religious group which he was affiliated. The Aum Shinrikyo sect also argued that they had done a 'great' sacred job when fighting the Government of Japan by releasing nerve gas killer «Nerin» in a subway station in Tokyo. No matter what sacral purpose they had for their actions, the label 'terrorist ' comes across anybody's mind when their names are mentioned.

Major mainstream influential powers in the world and the policy direction of the intense media campaign in the publicity have a dominant role in determining to which group the label of terrorism is pinned. The geo-political discourse situation and international policy also have the same contribution involved. William F. Shugart II noted that since the end of the Second World War there are three categories of violent actions which have been labeled terrorism based on the type of background and purpose. First, shortly after the end of World War II, violent actions that had implications for terror generally grounded by separatism and the purpose of the formation of the new sovereign state. The nature of his movement was limited and its scope was domestic. Second, starting around the 1960s until the fall of the Berlin wall in 1989, terrorism began to take shape as the movement of a populist left-wing which was inspired by the view of anti-Western liberalism and antiAmericanism to be more specific. The context of the cold war between the U.S.-led Western bloc and the Soviet-led Eastern bloc, added color to violent terror actions in this period, in which terrorism was seen as the Eastern bloc with sporadic attacks using extreme factions to attack the Western interests in different parts of the world. This is the phase that is often seen as the starting point of the 'globalization' of terrorism. Third, the final evolution of the wave of terrorism incarnated in the form of religion-based violence, in particular Islam. This form of terrorism is the ultimate evolution of the previous series and has been transformed in such a way that it became more brutal and terrifying. Why is the third wave of the form of terrorism often associated with Islam and described as "so terrifying"?

Further description of the classification put forward by Shugart II indicated that: first, terrorism is often interpreted simply as violent actions that create a terrifying atmosphere to get attention from many people. Second, terrorism almost has always been linked to anti status quo movements that oppose the legitimate power. Third, the trend of 
world political discourse is instrumental in determining the realm where terrorism issues are centralized. The end of the cold war that was marked by the collapse of the Soviet Union immediately ended the main focus of global political discourse surrounding the conflict between the West and the East, which has lasted for almost three decades. In the middle of the race, the news surrounding the actions of violence involving Muslims dominated the international media publicity. Resistance fought by some Muslim groups against the oppression of the rulers in a territory that received support of moral sympathy, funds, even soldiers and arms from other Muslim groups is seen as a phenomenon of a new trans-national violent conflict, especially when the excess of political violence then targeted vital interests of the West and led to a large number of casualties. Victims of violence involving Muslim groups throughout the 1990s reached three times of the total number of victims of terrorism in the four decades before.

Analysts further indicated that the roots of political violence in this new phenomenon is inspired by the rise of two Muslim groups who throughout history have always opposed each other; The Iran revolution initiated by the Shia and the success of the Mujahideen, who were Sunni majority , in expelling the Soviets from Afghanistan. The motives of fighting in the name of Islam with the sacred goal by Islamist groups is seen as a more effective way than revolutionary resistance. These conclusions can illustrate why terrorism discourse then evolved from political violence to religion-based violence and then put Islam as a focus of discourse as a leading role in terror and terrorism.

In a number of influential sources which will be discussed in the next section, the construction of the narrative discourse of terrorism involving Muslims even tends to be overstated. Some of the new terms like terrorism or the essentialist terrorism emerged with a euphemistic language that actually has sinister implication in the meaning. A series of violent acts that are seen as terrorism with Islam as the main culprit is often referred to by the term the 'new' terrorism' because it is different from conventional terrorism with only limited political aims. Islamic terrorism is oriented toward total destruction with a lot of casualties and losses on the side of the target and is seen as a justification of dogmatic basis. The Muslim perpetrators were often viewed as the essentialist terroristsbecauseoftheirviolentfanaticalfundamentalistbasis, and theyarefond of massacring people whom they consider infidels. Therefore, the approach to counter-terrorismagainst it mustalso employnew methods, and conventional criminal law is not sufficient as the solution. To understand completely 
about how Islamic terrorism discourse is formed and its construction characteristics shaped can be traced through the following discussion.

\section{THE GENEALOGY OF DISCOURSE OF ISLAMIC TERRORISM}

The genealogical discourse approach is based on the fact that a text always refers to other texts that also rely on texts that have been there before. Thus, the discourse forms a way of looking through a mechanism that involves the use of linguistic resources and system arrangement of the existing culture in interpreting a particular social phenomenon. The use of this genealogical approach here is expected to help to understand how «knowledge» formed today is formulated through a process of naturalization which took place in the span of time, space and discursive practices. Many aspects of the details that could be used to explain the origin of the construction of the discourse of Islamic terrorism. However, there are at least three common explanations that could describe how the concept of Islamic terrorism that is understood and used in its present form.

First and foremost is that the narrative discourse of 'Islamic terrorism' which is under discussion right now is based on assumptions, theories and concepts of knowledge which had been established in the field of study scope of terrorism. Although this narrative discourse is thriving and became the focus of an independent academic study and was recognized after the terrorist attacks of 11 September, the concept of 'Islamic terrorism' seems to have emerged since two previous few decades ago. Its origin stems from the concept of 'religious terrorism'. The concept most widely used and cited by influential literature afterward is 'religious terrorism' which was developed by David Rapoport in his paper entitled «Fear and Trembling: Terrorism in Three Religious Traditions", published in the journal of the American Political Science Review in 1984. From the work of Rapoport, a number of core texts were written by other influential academics, creating a reputation as a major source of reference in the study of ' Islamic terrorism : Concepts, narrative construction as well as the labels that became the core of discourse analysis developed by these past references then gained a strong authority and were very influential politically. The factor that helped to shape it was a close tripartite network connection between academics specializing in terrorism with a circle of power holders of policies that are also supported by senior journalists in several influential international media.

Second, the core focus of the study which became central in the discourse of 
Islamic terrorism as well as the pattern of narration and labels used in it was derived from a long tradition in the orientalist studies of the Middle East and religious studies in the Arab culture. The literature of the orientalist studies was growing rapidly following the tumultuous events in the Middle East in the 1970s and 1980s such as the massacre of the 1972 Olympic Games in Munich, the world oil crisis in 1973, the U.S. Embassy hostage-taking crisis in Iran that accompanied the revolution in 1979, the case of Salman Rushdie, as well as terrorism cases involving kidnapping and piracy throughout the 1980s. This type of trend in the orientalist studies then became more intense with the 9/11 attacks and the war campaign against terrorism. One of most dominant literatures that affects the study of international relations with the nuances of the orientalist viewpoint was the work of Samuel Huntington entitled "the Clash of Civilization?". The essay written in 1993 and the title quoted from the work of Bernard Lewis became an important antecedent and was reproduced in many other works in Islamic terrorism discourse circulating nowadays. In addition, figures like Bernard Lewis, Noah Feldman, Raphael Patai and other orientalist experts in the Middle East studies more often shared ideas with other experts in the field of terrorism and became major advisory and expert staff for the U.S. Government in the formulation of the action against terror. This became the catalyst for the transmission of orientalist viewpoint that subsequently shaped the discourse of Islamic terrorism in the political policy process.

Third, many Islamic terrorism discourses refer to a long tradition of cultural stereotypes and representations of one-sided media that often portray Islam and Muslims as the 'enemy'. In describing the Muslims, the mainstream media usually tend to use a framework with a focus on violence, threats, extremism, fanaticism and terrorism, although there is also some visual tradition of the orientalists in which Muslims are portrayed as exotic and mysterious. Imaging representation of cultural forms like this has survived for so long and embedded so strongly. The reason is that the viewpoint reflects the socio-culture of the West's fear and anxiety that the other side which is oriental is often stereotyped, and this has been going on since the imperial period. Many also argued that the dichotomous viewpoints of the orientalists of us and they has intentionally been preserved as a form of imperialism in a new style.

In addition to the three primary discursive traditions above, especially after the event of 9/11, the discourse of 'Islamic terrorism' also inherited the concepts and terms that had been used in narratives of cultural discourse of earlier global politics. Idioms such as 'good war' for example is a discourse which 
was often used by the Western allies in the fight against fascism in World War II and the cold war. Likewise, with other terms such as 'civilized vs. barbaric war', 'rogue states', 'enemy within',weapons of mass destruction, the eternal battle between good and evil is a series of old cultural narrative that is now the central exposure that decorate the discourse of the so-called 'Islamic terrorism'.

\section{THE CORE ELEMENTS OF THE NARRATIVE DISCOURSE OF 'ISLAMIC TERRORISM'}

The narrative discourse of Islamic terrorism is built on a foundation that includes the main concepts in the form of assumptions and labeling that are formed of a series of terminology. The majority of Islamic terrorism discourse quoted the major terms such as 'Islamic world', 'the West', 'the rise of Islam,' 'political Islam,' 'Islamism', 'extremism', 'radicalism', 'fundamentalism, 'religious terrorism,' 'Jihad', 'Wahhabi', 'Salafi, 'militant,' 'moderate, 'global Jihad movement', 'al-Qaeda', and of course, the 'Islamic terrorism'. Unfortunately, however, the above terms in the textual use often refer to the unclear intent. The definition often gives rise to misinterpretation and even is filled with stereotypical cultural bias.

In addition, a series of labels and the terms above are generally put together in such a way and then presented in a dramatic binary opposition. The term 'Islamic world' for example is narrated in opposition to the culture of 'West〉. Similarly, other concepts such as extremist vs moderate, totalitarian vs democratic, secular versus religious, civilized vs barbaric. Extreme polarization within the narrative discourse seems to be intentionally enabled to build a frame of 'Islamic terrorism' and 'extremists', as the real-life entities in the overall story and stands opposite the other entities such as speaceful society' 'democratic State' or 'moderate Muslims' for example. More importantly, the construction in this discourse also often negates another identity which is also so prominent on a narrative central actor's character into the spotlight. The application of labels such as 'terrorists', 'fundamentalist' and 'extremist' to groups such as Hamas and Hezbollah, for example, with the immediate obscurity of the fact that they basically play the role of political parties, social welfare, social welfare activists, charitable aid agencies, educational institutions, guerrilla forces and so on. In the narrative of Islamic terrorism, these groups are often simplified as the enemy of Western society.

This discourse also often includes a series of qualifications carefully designe $\mathrm{d}$ to limit the scope of the label, the narrative and the assumption that in the context of political or other cultures would be considered degrading. Therefore, it is commonly found in the text of the studies on «Islamic terrorism " 
which began with statements such as: "the majority of Muslims are actually practicing peaceful and inclusive religion [...]", "[unfortunately].. Islamic terrorists are inspired by the teachings that deviate from Islam and their sacred campaign of violence through the choice of verses extracted from the Qur'an". But then, after that statement, almost the whole expression of the discourse directly discredits Islam and other religious aspects associated within it. Although the texts about the discourse of Islamic terrorism so broadly spread and easily found, the entire discourse is nonetheless filled with biased materials (prejudice) against Islam.

\section{THE MAIN CHARACTERISTICS OF THE NARRATIVE DISCOURSE OF ISLAMICTERRORISM}

Each discourse is never uniform, coherent or consistent. Each has fragile limitations (debatable) and there are many exceptions, inconsistencies and contradictions between one text and another engaged in such discourse. 'Islamic terrorism experts ' generally presented their discourse in phrases that shaped the arguments either in the form of support or opposition. They contributed with a different methodology background in describing the main characteristics of narrative discourse which they get into. In some cases, some of them even seemed to disregard the constraints of an actual narrative character they are building when focusing on the argument for opposition. However, if their works are put together in one clump of discourse then it will generate a narrative construction with some typical specifications and functions as a concept jointly understood within the context of culture and politics. Through such a chronology of the main characteristics of the narrative, ‘Islamic terrorism' is formed, and the illustration of the assumptions, label, as well as its central narrative can be seen clearly in some parts.

The most important central axis of the whole discourse of Islamic terrorism comes from a major assumption that violence being a fundamental factor in the cause of terrorism is inherent in the teachings of Islam. The reason of this assumption is that unlike Christianity, which has strict lines of distinction between the 'Church' (religion) and State (politics), Islam does not recognize the distinction between the sacred and the profane, between religion and politics, and therefore still perpetuates the teachings of war in the name of religion (religious war). In the majority of the texts, Islam is always described as a religion which regulates both private and social life so as to impact in the formation of the characteristics of the political life of its followers. These concepts are often used as the main pillar of the argument in the dominant contribution of Islam with regards to religious violence. Walter Laquer -one of the most respected figures in the study of terrorism for example- mentioned that although no 
Arab or Muslim monopoly term in the field of religious fanaticism, the frequency of acts of terrorism involving Muslims and Arabs are so striking, and meanwhile the discussions surrounding the religious backgrounds of terrorism may not be limited just by highlighting radical Islam. "It cannot be denied that, in fact, Muslim countries occupy the top position in the spotlight," he said. With the same tone, Barak Mendelsohn said that the extremists who wanted to impose religious law as the basis for the State exist in all religions, but religious terrorism just seemed so real in Muslim societies.

Such open expressions with similar narration are scattered in the media. In addition to the rude statement of Samuel Huntington who mentioned that "Islam has a bloody borders", an awful lot of exposure to other natural inherent relationship to associate Islam with political violence on the basis of 'facts' that Islam does not separate religion and politics. One of the publications of a leading counter-terrorism think-tank, for example, viewed that in the Islamic world political violence committed by Muslim groups cannot be separated from the basics of religious belief. Actions of terrorism that happened in parts of the Arab and Muslim world are inborn nature of Islam itself.

The other major characteristics which are directly related to the narrative above are a view of the actions of terrorism that has always been related to or arise and is inspired by the form of the practice or interpretation of Islamic fundamentalism and extremism. Some texts for study of terrorism even always build axiomatic link between terrorism and actions carried out by Islamist groups, Salafi or Wahabi. Magnus Ranstorp in his work generalized that every Islamist movement has an underbow of activities in the world of terror without detailing specific qualifications in the categorization. Reuven Paz of the International Policy Institute for Counter-Terrorism (ICT) wrote about the 'culture of terrorism in Islam' and ideology, doctrine and activities of violence in Islam. Paz indicated that violent actions are culturally and firmly embedded in Islamism. So is the case with Marc Sageman who is also one of the prominent experts in the study of terrorism. By taking the focus of studies on global Salafi Jihad movement and 'terrorist group' of the Salafi group affiliated with al Qaeda, concluded that the ideology of Salafi is an inspiration from the determination of the mission form, goal setting, and supervising the tactics of terror actions they carry out. Furthermore, according to Sageman, Al-Qaeda is not only limited to terrorist organization involved in the political sphere but also in the socio-religious revivalist movement. The connection between the concepts of terrorism and extremism found in the discursive formation above subsequently forms a structure of 'knowledge' that resonates in the public realm that Islam by nature is very violent and terroristic. 
In addition to the explicit labeling way like the explanation above, there is also a relationship between narrative characterization of Islam and violence and terrorism wrapped in a more implicit way. Such characterization is implied in any representation that lays out the roots of terrorism in Islam. The narratives generally detail some of the core concepts that come from the teachings of Islam such as Jihad, Sharia, Shahada, Dar al-Islam, Dar al-Harb, Jaahiliyya, Ummah, Takfir, and so forth, as well as how Muslim scholars like Say yid Qutb or Muhammad Ibn Wahhab interpreted it. With such narrative, a common assumption emerged that groups like al-Qaeda or other Islamic radical movements are basically recognized theologically as the followers of Islam among Muslims. And therefore, the ideology and the doctrines that inspired actions of terrorism are part of mainstream Islam as a whole. The characteristics of this kind of discourse, intentionally or not, leading to a strengthening of the perception that real violence or terrorism really appears from or even stems from the teachings and practices of Islam. Then the conclusion in the end is that Islam is in fact the core of the threat of terrorism, or in the language of one of the observers of the Foreign Policy Center: "The Jihadist can be found in almost any place that Muslim communities can be found".

Another characteristic of the core narrative of this discourse is that the actions of 'Islamic terrorism' are driven by religious motives or sacred reasons than considerations of a political or ideological motivation. A lot of the goals expressed by the 'Islamic terrorists' are generally centered around combating and destroying Israel and Western dominance, undermine the authority of the regime in the Muslim lands, the return of Muslims to the Islamic teachings which form true and pure and re-establish a Caliphate of Islamic order. Shaul Mishaal and Maoz Rosenthal, for example, argued that the longterm goals of the Islamic extremists are to change social and political order in countries that the majority of the population are Muslim by an Islamic State governed by Islamic law. David Cook even went so far as to declare that a radical Islamic Group has a large main goal of uniting all Muslims in an Islamic State and subsequently lead them to dominate the world.

Because the goal was strongly influenced by the sacred motivation, Islamic terrorism in subsequent discursive formulations tends to be identified as an anti-modern, anti-secular and anti-democratic movement. Ranstorp insisted that concerns over infiltration of secularization from foreign parties are a catalyst for the emergence of actions of religious terrorism. These radical groups, Ranstorp said, are driven by the background of 'xenophobic' motivation against everything that comes from foreign or secular parties as well as a strong sense of rejection of Western culture. Similarly, Benjamin Barber 
also argued that the 'army' of Jihad despised modernity secular, scientific, rational and commercial culture that they think are derived from European Re naissance culture. In fact there are also texts in narrative discourse which describe it with a very rude expression. Ayla Schbley in a leading journal entitled Studies in Conflict and Terrorism stated that public disapproval of the democratization and modernity in the Islamic world is due to the fact that Muslims tend to continue to engage in violence because for them the concept of nation-states and democracy looks like pork and its rind.

Moreover, 'Islamic terrorism ' is also often narrated as actions which are based by a sense of deep hatred against America and the West. This sense of hatred is caused by anger and a sense of impotence in the course of history where Muslims once ruled the world in one stretch of time then experienced a failure in economic development and modernization, the defeat in the conflict against the forces when dealing with Israel, and their inability to reduce the pace of the process of globalization and secularization. Takeyh and Gvosdev indicated that a radical Islamism is an ideology of hate and terror aiming to undermine the existing order. While Bernard Lewis argued that Islamic fundamentalism has inspired direction and format of the movement from the condition of despair, resentment, and anger of the Muslims before the power that has diminished their pride and traditional values. This narrative then leads to an assumption which concludes that among the main goals of the mission of Jihad is to restore the pride and glory of the Muslims in the presence of the New World Order that is sponsored by the West.

One of the characters in the narrative that may be the most important part of this discourse is the assumption that 'Islamic terrorism' is the greatest threat to Western security and stability. In a variety of texts, one can easily find expressions and impression that 'Islamic terrorism' has always been one of the most significant threats to the national security of Western Nations in general and the United States in particular. Quoting the main characteristics with narrative 'Islamic terrorism', Sageman explained the shape of such threats as follows:

"A new type of terrorism threatens the world, driven by networks of fanatics determined to inflict maximum civilian and economic damages on distant targets in pursuit of their extremist goals. Armed with modern technology, they are capable of devastating destruction worldwide. They target the West, but their operations mercilessly slaughter thousands of people..."

The form of assumption derived from this narrative seems to serve as the basis for many of the underlying policies issued by the U.S. Government. They tend to believe that 'Islamic terrorism' has enormous potential that 
threatens the sustainability of the cultural order of Western democracy and the overall view of its life. They also seem so sure that 'Islamic terrorism' receives support from 'dangerous' rogue regimes and the sympathy of millions of good Muslims who live in Muslim countries as well as in the West. Daniel Pipes, for example, indicated that the enemy of the West is the militant Muslims with a number reaching 10-15 percent of the total population of Muslims in the world totaling more than 1 billion adherents. This means that the US has a potential threat of attack from about 100-150 million Muslim militants who may become its enemies. Pipes then assumed that although no poll survey conducted in the middle of the Muslim community population, he believed at least half of the total, or about 500 million Muslims would be more sympathetic to Osama bin Laden and the Taliban than to the U.S. Government.

Narrative discourse regarding the threat of 'Islamic terrorism' is also closely related to the discourse surrounding the 'mythology' of al-Qaeda terrorist network and the group called «Afghan〉 Jihad. Generally, this narrative confirms the existence of the thousands of volunteers who have experienced a militant Jihad training and combat in the war against the Soviet Union in Afghanistan and they are now linked in a global network. Jessica Stern indicated that at the time of the September 11, 2001 tragedy there were at least 70,000 to 110,000 Muslim radicals who have graduated from the al-Qaeda training camp. Another analysis calculated the chances of their number was between 35,000 and 50,000 worldwide, all of whom were operatives, some were moving independently, mostly in standby position, and ready to commit holy war against the West. They also get support from six million more who are scattered in other radical Muslim countries in all corners of the world. The description formed by this discursive construction model is a concept that Islam and the Muslim world is a 'direct threat' and dangerous for the existence of the West.

The narrative of potential threat of 'Islamic terrorism' above borrows concepts, perspectives and labeling that come from the field of study of previous general terrorism, especially ideas that illustrate that the world is facing a new kind of 'terrorism'. The theories of the 'New Terrorism' mentioned special specifications of this new kind of terrorism that is identified with the violent actions that are rampant in the Muslim world. Characteristics that are often expressed are among others domination of background of hate motivation, fanaticism and extremism with a political ideology; a new type of terrorism is inspired by the teachings of the religion and is determined to inflict mass casualties among civilians; the culprit is ready to sacrifice them- 
selves in an action for assault or murder, and they are also ready to use weapons of mass destruction. Finally, the picture that emerges is the world facing a more cruel form of terrorism. Ranstorp said that the violent actions committed by religious extremists know no boundary of humanity because they do not recognize moral constraints in using violence. Stern also argued that this terrorist group is more dangerous than the secular one, and the possibility that they use weapons of mass destruction is far more open.

The important narrative form subsequently constructed is that since «Islamic terrorism > is full of religious bigotry, irrational and deadly, then there is no reason to open the space for negotiations, let alone compromise for peace. The only way to deal with the phenomenon of 'Islamic terrorism' is the method of eradication and prevention and enforced by other counter-terrorist actions. One of the distinctive expressions representing this narrative is expressed by Daniel Byman, «the wide coverage of the issue of the terrorist group's agenda such as those of al-Qaeda that are trying to spread hatred and Jihad propaganda as the only way out, then making peace with them is difficult in theory and impossible in practice". With similar patterns, Barber asserted that the purpose of the Islamic terrorist group that absolutely cannot be negotiated is rationalized. According to him, the terrorists never give any option and therefore have to be countered and eradicated up to its roots. Expressions that are often used in this discourse in the political landscape are reflected in the statement of Tony Blair. He stated that "You just need to pay attention to the demands of al-Qaeda to understand that you will never be able to compromise with them. The only choice you will be defeated by them or move to defeat them"

Other elements of the narrative the 'New Terrorism $>$ used in the construction of the discourse of 'Islamic terrorism' is a description that is different from the traditional terrorist groups that have an organized hierarchy, the 'Islamic terrorists' have a decentralized structure with a flexible network. Analysts from the RAND Corporation argued that a new breed of the actions of terrorism has evolved towards a form net-war. Islamic fundamentalist organizations such as Hamas and the network under the leadership of Osama bin Laden are composed of many inter-connected sub-groups. They form semiindependent cells that do not have a single command hierarchy. Chatham House also released a report which described al-Qaeda as a 'network of networks' with membership scattered in at least 60 countries. This jihad network is also utilizing the internet and other modern technologies as a medium in dissemination of messages, individual indoctrination, recruitment of new members, coordination of activities, operational information shar- 
ing, as well as fundraising and moral support. Their movement can be said to be a 'techno-terrorism' because it makes use of satellite communications, email and the World Wide Web in their action.

This narrative sees those facts as an irony. The groups of 'Islamic terrorism' use modern technology in order to pursue the objectives of going back to the way of life to the medieval age. Barber, for example, stated that Osama Bin Laden without modern media will look like a desert rat that would never have been known. His opinion on terrorism without the credit card, the global financial system, modern technology and the internet, the impact will only be like throwing a rock at the head of a sheikh on the street. At the end of its conclusion, the purpose of this narrative construction apparently is to reinforce the impression of the scope of the danger that may be caused by terrorist groups and that to fight them is very difficult and that methods destruction and eradication are the only appropriate response in dealing with them.

\section{CLOSING REMARKS}

The general characteristics of the 'Islamic terrorism' related to the narrative the perpetrators of terrorism are that they exploit a charitable institutions as well as other Muslim NGOs to raise funds and divert its use to support the actions of terrorism. Byman, for example, argued that the 'Islamic terrorists' are connected to a broader network that includes charitable institutions in Chechnya, organizers of Islamic education in Southeast Asia, and fundraisers in Europe. Network connection from their NGOs is essential. These NGOs in fact serve as a way for them to raise funds, and they provide employment for the terrorist activists, channel the funds, and provide required documents (supporting action). Paul Pillar also identified some Muslim NGOs involvement either intentionally or not in the event of terrorism. Meanwhile, the Foreign Policy Center said that many Muslim NGO fundraisers turned out to be terrorist organizations that escaped the detection of authorities. As mentioned earlier, this type of narrative discourse serves to reinforce the concept of the importance of identifying and overseeing Muslim organizations scattered in many places. Although they look normal in everyday life, the danger they might pose should always be looked out for.

The characteristics of the other narrative are that the 'Islamic terrorism' must be combated even in the form of concept and idea. Moderate Muslims must become a leading figure in the fight against the growing extreme pragmatism in their environment. Zeyno Baran, for example, argued that the central task in counter-terrorism is to find formulations to help moderate Muslims to win the theological and ideological civil war currently in prog- 
ress against the extremists in the Muslim world. Patricia Hewitt also suggested that parties who shoulder the responsibility of leadership must immediately stand up against any malicious propaganda which are constructed and imposed by Islamic extremists in the middle of the Muslim community. This narrative construction at least implies an effort to build understanding of the two concepts. First, there is a clear line of separation between the 'moderate' Muslims and the 'extremists'. Second, terrorism generally is an internal issue of the Islamic world and it is the responsibility of the Islamic world to fix it.

Other narrative forms are also easy to find in the literature of 'Islamic terrorism' includes concepts such as: first, the 'Islamic terrorism' and 'extremism' by Muslims living in the middle of the Western societies are due to the lack of integration, failure of multiculturalism, alienation and unemployment as well as the influence of radicalization of the Jihad groups from the outside; second, the Muslim communities in Western countries are often termed 'the fifth column' or the enemy in the enemy within that is either actually or potentially very dangerous; third, the 'Islamic terrorist' generally consist of young men who are weak and vulnerable psychologically as well as less educated so that they are easily indoctrinated and brainwashed. They are easy to fall into extremist propaganda through radicalism in the madrasahs, mosques or internet sites. Those involved in the actions of suicide bombings were allegedly young men who were primarily driven by a sense of frustration and sexual impotence.

\section{End Notes:}

William F. Shugart II, "An Analytycal History of Terrorism",.. hal. 27-32

Lihat misalnya, Bruce Hoffman, Inside Terrorism, hal. 18, 92-93, 123, R. Hardin, One for all: The logic of group conflict. (Princeton, NJ: Princeton University Press, 1995), hal. 216, P. R. Pillar, , (Washington, DC: Brookings Institution, 2001), hal. 121, National Commission on Terrorist Attacks upon the United States (2004, pp. 59, 60, 62, 70, 71, 98, 100, 180, and 190). Untuk informasi yang lebih lengkap lihat US Department of State, "Significant Terrorist Incidents, 1961-2003: A Brief Chronology", at http://www.state.gov/r/pa/ho/pubs/fs/5902pf.htm.

Wacana keabsahan pendekatan counter-terrorism ini mengemuka ketika perbincangan seputar pelanggaran HAM terhadap tahanan-tahanan tersangka Taliban dan al-Qaeda di penjara Guantanamo menjadi fokus pemberitaan media global. Pihak-pihak yang mendukung penahanan tanpa proses pengadilan menggunakan pendekatan essentialist terrorism ini sebagai pembenaran.

Roxanne Doty, "Foreign Policy as Social Construction: A Post-Positivist Analysis of U.S. Counterinsurgency Policy in the Philippines", International Studies Quarterly, 37 (1993), hal. 297-320. Lihat Juga Jennifer Milliken, "The Study of Discourse in International Relations: A Critique of Research and Methods", European Journal of International Relations, 5:2, (1999), Hal. 225-54.

David Rapoport, 'Fear and Trembling: Terrorism in Three Religious Traditions', American Political Science Review, 78: 3 (1984), pp. 658-677

Diantara beberapa literature yang banyak dikutip oleh karya-karya lain dalam bidang kajian terrorisme dan Islam adalah Bruce Hoffman, Inside Terrorism, (NewYork: Columbia 
University Press, 1998), kemudian Walter Laqueur, The New Terrorism: Fanaticism and the Arms of Mass Destruction, (New York: Oxford University Press, 1999), Mark Juergensmeyer, Terror in the Mind of God: The Global Rise of Religious Violence, (Berkeley, CA: University of California Press, 2000), Jessica Stern, Terror in the Name of God: Why Religious Militants Kill, (New York: HarperCollins, 2003), dan Magnus Ranstorp, 'Terrorism in the Name of Religion', Journal of International Affairs, 50: 1 (1996), pp. 41-62.

Indikasi fakta dari koneksi akademisi-birokrat-jurnalis ini adalah bahwa penulis-penulis seperti Bernard Lewis,

Bruce Hoffman, Steven Simon, Jessica Stern, Daniel Benjamin, dan Richard Perle pernah bekerja di badan-badan strategis pemerintah seperti national Security Council dan Kementrian Pertahanan AS. Mereka juga saling bertukar informasi dengan wartawan-wartawan senior di CNN, VoA, The New York Times, LA Times, Washington Post, Newsweek dan USA Today seperti Thomas Friedman, Charles Krauthammer, David Brooks, William Kristol, Martin Peretz, Norman Podhoretz, dan Judith Miller. Lihat L. Ali Khan, Phenomenology of International Terrorism: Understanding Islamic Militancy, (Leiden: Martinus Nijhoff Publisher, 2006), hal. 206-209.

Lihat misalnya Fred Halliday, Two Hours that Shook the World - September 11, 2001: Causes \& Consequences, (London: Saqi Books, 2002), hal. 88-131. Untuk gambaran detail lebih lanjut mengenai bagaimana kultur orientalis mewarnai studi Islam lihat Edward Said, Covering Islam: How the Media and the Experts Determine How We See the Rest of the World, (London: Vintage, 1981), revised edition 1997 dan Yahya Sadowsky, 'The New Orientalism and the Democracy Debate, dalam Joel Beinin and Joe Stork (eds), Political Islam, (Berkeley, CA: University of California Press, 1996).

Samuel Huntington, 'The Clash of Civilizations?', Foreign Affairs, 72: 3 (1993), hal. 22-49. Sedangkan karya Bernard Lewis yang dimaksud adalah Bernard Lewis, 'The Roots of Muslim Rage', Atlantic Monthly, 266: 3 (1990), hal. 47-60

As'ad AbuKhali, 'Book Review: "The Islam Industry” and Scholarship', Middle East Journal, 58: 1 (2004), hal. 130-8. Lihat juga, Edward Said, Covering Islam, hal. 150

Banyak sekali karya yang mengulas mengenai peran media khususnya di Barat yang merepresentasikan pandangan stereotype terhadap Islam. Beberapa diantaranya seperti Elizabeth Poole and John Richardson, Muslims and the News Media, (London: I.B. Tauris, 2006); Kai Hafez (ed.), Islam and the West in the Mass

Media: Fragmented Images in a GlobalizingWorld, (Cresskill, NJ: Hampton Press, 2000); John Richardson, (Mis)Representing Islam: The Racism and Rhetoric of British Broadsheet Newspapers, (Amsterdam: John Benjamins, 2004); dan Jack Sheehan, Reel Bad Arabs: How Hollywood Vilifies a People, (Northampton, MA: Interlink Publishing Group, 2004) Elizabeth Hurd, 'Appropriating Islam: The Islamic Other in the Consolidation of Western Modernity’, Critique: Critical Middle Eastern Studies, 12: 1 (2003), Hal. 25-41.

Lihat misalnya tulisan-tulisan dalam buku K. El Fadl (ed.), Shattered Illusions: Analyzing the War on Terrorism, (Bristol: Amal Press, 2002)

Bahasan mendalam seputar issu historiografi narasi cultural dalam kaitannya dengan kampanye War on Terror pimpinan AS dapat ditemukan dalam Richard Jackson, Writing the War on Terrorism: Language, Politics and Counterterrorism, (Manchester: Manchester University Press, 2005). Lihat juga Stuart Croft, Culture, Crisis and America's War onTerror), (Cambridge: Cambridge University Press, 2006).

The 9/11 Commission, Final Report of the National Commission on Terrorist Attacks

Upon the United States, (New York: W. W. Norton \& Co., 2004), hal. 54

Ray Takeyh and Nikolas Gvosdev, 'Radical Islam: The Death of an Ideology?', Middle East Policy, 11: 4 (2004), hal. 86

Lihat misalnya Barak Mendelsohn, "Sovereignty Under Attack: The International Society Meets the Al Qaeda Network”, Review of International Studies, 31 (2005), hal. 55.

Walter Laqueur, The New Terrorism, hal. 129

Barak Mendelsohn, "Sovereignty Under Attack...”, hal. 57

Samuel Huntington, “A Clash of Civilizations?”, hal. 35. Lihat Juga Magnus Ranstorp, 
"Terrorism in the Name of Religion", hal. 43.

Habib Malik, "Political Islam and the Roots of Violence", in Elliott Abrams (ed.), The Influence of Faith: Religious Groups and U.S. Foreign Policy, (Lanham, MD: Rowman \& Littlefield, 2001)

Reuven Paz, "Is There an 'Islamic Terrorism'?”, International Policy Institute for Counter-Terrorism (ICT) Publication, Herzilya, Israel, 7 September 1998, atht tp://www.ict.org.il/ articles/articledet.cfm?articled=46, diakses pada tanggal 05 Desember 2012,

Magnus Ranstorp, "Terrorism in the Name of Religion", hal. 58

Reuven Paz, "Radical Islamist Terrorism: Points for Pondering”, International Policy Institute for Counter-Terrorism (ICT) Publication, Herzilya, Israel, 20 June 2001, at http://www. ict.org.il/articles/articledet.cfm?articleid=367, diakses tanggal 05 Desember 2012

Marc Sageman, Understanding Terror Networks, (Philadelphia: University of Pennsylvania Press, 2004), hal. 1.

Marc Sageman, Understanding Terror Networks, hal. 126

Lihat misalnya Daniel Benjamin \& Steven Simon, The Age of Sacred Terror, (New York: Random House, 2002); Paul Berman, Terror and Liberalism, (New York: W.W. Norton, 2003); Natana DeLong-Bas, Wahhabi Islam: From Revival and Reform to Global Jihad, (Oxford: Oxford University Press, 2004); dan Raphael Israeli, “A Manual of Islamic Fundamentalist Terrorism", Terrorism and Political Violence, 14: 4 (2002), hal. 23-40.

Quintan Wiktorowicz, “A Genealogy of Radical Islam”, Studies in Conflict \& Terrorism, 28 (2005), hal. 75

Greg Austin, The Next Attack: 'Know Your Enemy and Know Yourself', (London: Foreign Policy Centre, 2005), hal. i.

Shaul Mishal and Maoz Rosenthal, "Al Qaeda as a Dune Organization: Towards a Typology of Islamic Terrorist Organizations", Studies in Conflict \& Terrorism, 28 (2005), hal. 277.

David Cook, "The Recovery of Radical Islam in the Wake of the Defeat of the Taliban", Terrorism and Political Violence, 15: 1 (2003), hal. 52

Magnus Ranstorp, "Terrorism in the Name of Religion”, hal. 49

Benjamin Barber, "Democracy and Terror in the Era of Jihad vs. McWorld", dalam Ken Booth and TimDunne (eds), Worlds in Collision: Terror and the Future of Global Order, (New York: Palgrave Macmillan, 2002), hal. 247

Ayla Schbley, "Religious Terrorism, the Media, and International Islamization Terrorism: Justifying the Unjustifiable”, Studies in Conflict \& Terrorism, 27 (2004), hal. 208

Takeyh and Gvosdev, "Radical Islam", hal. 93

Bernard Lewis, "The roots of Muslim Rage".

Jessica Stern, "Terror in the Name of God", hal. 264

Saul Mishal and Maoz Rosenthal, “Al Qaeda as a Dune Organization”, hal. 276

Sageman, Understanding Terror Networks, hal. Vii.

Daniel Pipes, “Who is the Enemy?”, Commentary, 113: 1 ( January 2002), hal. 23-24, 26, artikel ini dapat juga ditemukan di http://www.danielpipes.org/article/103, diakses pada tanggal 05 Desembert 2012

Marc Sageman, Understanding Terror Networks, hal. 25-59.

Jessica Stern, Terror in the Name of God, hal. 260.

Gus Martin, Understanding Terrorism: Challenges, Perspectives, and Issues, (London: Sage, 2003), hal. 194, 198.

Rohan Gunaratna, Inside Al Qaeda, (New York: Columbia University Press, 2002), hal. 8,95 .

Beberapa literature yang mencuatkan teori baru "The New Terrorism" ini diantaranya adalah Ian Lesser, et al., Countering the New Terrorism, (Santa Monica, CA: Rand Corporation Publications, 1999); Charles Kegley, Jr. (ed.), The New Global Terrorism: Characteristics, Causes, Controls, (New Jersey: Prentice Hall, 2003); dan Russell Howard and Reid Slayer (eds), Terrorism and Counterterrorism: Understanding the New Security Environment, (Guildford: McGraw-Hill, 2003); disamping tentunya karya Bruce Hoffman, Inside Terrorism, dan Walter Laquer, The New Terrorism. 
Magnus Ranstorp, "Terrorism in the Name of Religion", hal. 54.

Jessica Stern, Terror in the Name of God, hal. xxii

Daniel Byman, “Al-Qaeda as an Adversary: Do We Understand Our Enemy?”, World Politics, 56 (2003), hal. 147

Benjamin Barber, "Democracy and Terror", hal. 246

Tony Blair, "PM's Press Conference”, 5 August 2005, at http://www.number10.gov.uk/ output/Page8041.asp, diakses tanggal 05 Desember 2012

RAND Corporation adalah sebuah lembaga penelitian kontra-terrorisme di bawah struktur Angkatan Udara Amerika Serikat.

John Arquilla, David Ronfeldt and Michele Zanini, "Networks, Netwar, and Information-Age Terrorism", dalam Ian Lesser et al., Countering the New Terrorism, hal. 56

Chatham House merupakan lembaga penelitian kontra-terrorisme yang dibentuk oleh dan berafiliasi sebagai penasehat bagi pemerintahan Inggris.

Frank Gregory and Paul Wilkinson, "Riding Pillion for Tackling Terrorism is a HighRisk Policy", Security, Terrorism and the UK, Chatham House ISP/NSC Briefing Paper 05/01, July 2005, hal. 2.

Frank Gregory and Paul Wilkinson, "Riding Pillion for Tackling Terrorism is a HighRisk Policy", hal. 65

Benjamin Barber, "Democracy and Terror", hal. 249.

Daniel Byman, "Al-Qaeda as an Adversary", hal. 151

Paul Pillar, "Terrorism Goes Global: Extremist Groups Extend their Reach Worldwide", Brookings Review, 19: 4 (2001), hal. 36

Greg Austin, "The Next Attack”, hal. 28

Zeyno Baran, "Fighting the War of Ideas", Foreign Affairs, 84: 6 (2005), hal. 84

NS interview, "Patricia Hewitt", Newstatesman, 25 July 2005, hal. 26.

Lihat misalnya laporan yang dikeluarkan oleh pemerintah Inggris yang berjudul "Draft Report on Young

Muslims and Extremism", UK Foreign and Commonwealth Office/Home Office, April 2004, dapat ditemukan di http://www.globalsecurity.org/security/library/report/2004/muslimext-uk.htm, diakses tanggal 05 Desember 2012

Lihat Javier Jordan and Luisa Box, "Al-Qaeda and Western Islam", Terrorism and Political Violence, 16: 1 (2004), hal. 1-17.

Jenis narasi ini terekspresikan dalam artikel Husain Haqqani, “Islam’s Medieval Outposts",Foreign Policy, 133 (2002), hal. 58-64.

Lihat misalnya Mark Juergensmeyer, Terror in the Mind of God, hal. 201.

\section{REFERENCES}

AbuKhali, As'ad, 'Book Review: "The Islam Industry" and Scholarship', Middle East Journal, 58: 1 (2004)

Austin, Greg, The Next Attack: 'Know Your Enemy and Know Yourself', (London: Foreign Policy Centre, 2005)

Baran, Zeyno, "Fighting the War of Ideas", Foreign Affairs, 84: 6 (2005), hal. 84

Barber, Benjamin, "Democracy and Terror in the Era of Jihad vs. McWorld", in Ken Booth and TimDunne (eds), Worlds in Collision: Terror and the Future of Global Order, (New York: Palgrave Macmillan, 2002)

Benjamin, Daniel, \& Simon, Steven, The Age of Sacred Terror, (New York: Random House, 2002)

Berman, Paul, Terror and Liberalism, (New York: W.W. Norton, 2003) 
Blair, Tony, "PM's Press Conference”, 5 August 2005, at http://www.number10. gov.uk/output/Page8041.asp, diakses tanggal 05 Desember 2012

Cook, David, "The Recovery of Radical Islam in the Wake of the Defeat of the Taliban", Terrorism and Political Violence, 15: 1 (2003)

Croft, Stuart, Culture, Crisis and America's War onTerror), (Cambridge: Cambridge University Press, 2006).

DeLong-Bas, Natana, Wahhabi Islam: From Revival and Reform to Global Jihad, (Oxford: Oxford University Press, 2004)

Doty, Roxanne, "Foreign Policy as Social Construction: A Post-Positivist Analysis of U.S. Counterinsurgency Policy in the Philippines", International Studies Quarterly, 37 (1993),

El Fadl, Khaled Abou, (ed.), Shattered Illusions: Analyzing the War on Terrorism, (Bristol: Amal Press, 2002)

Gregory, Frank, and Wilkinson, Paul, "Riding Pillion for Tackling Terrorism is a High-Risk Policy", Security, Terrorism and the UK, Chatham House ISP/NSC Briefing Paper 05/01, July 2005

Gunaratna, Rohan, Inside Al Qaeda, (New York: Columbia University Press, 2002), hal. 8, 95.

Hafez, Kai, (ed.), Islam and the West in the Mass Media: Fragmented Images in a GlobalizingWorld, (Cresskill, NJ: Hampton Press, 2000)

Halliday, Fred, Two Hours that Shook the World - September 11, 2001: Causes \& Consequences, (London: Saqi Books, 2002)

Haqqani, Husain, “Islam's Medieval Outposts”, Foreign Policy, 133 (2002)

Hardin, R., One for all: The logic of group conflict. (Princeton, NJ: Princeton University Press, 1995)

Hoffman, Bruce, Inside Terrorism, (New York: Columbia University Press, 1998)

Howard, Russell, and Slayer, Reid, (eds), Terrorism and Counterterrorism: Understanding the New Security Environment, (Guildford: McGraw-Hill, 2003)

Huntington, Samuel, 'The Clash of Civilizations?', Foreign Affairs, 72: 3 (1993)

Hurd, Elizabeth, 'Appropriating Islam: The Islamic Other in the Consolidation of Western Modernity', Critique: Critical Middle Eastern Studies, 12: 1 (2003)

Israeli, Raphael, “A Manual of Islamic Fundamentalist Terrorism”, Terrorism and Political Violence, 14: 4 (2002)

Jackson, Richard, Writing the War on Terrorism: Language, Politics and Counterterrorism, (Manchester: Manchester University Press, 2005)

Jordan, Javier, and Box, Luisa, "Al-Qaeda and Western Islam", Terrorism and Political Violence, 16: 1 (2004) 
Juergensmeyer, Mark, Terror in the Mind of God: The Global Rise of Religious Violence, (Berkeley, CA: University of California Press, 2000)

Kegley, Jr., Charles, (ed.), The New Global Terrorism: Characteristics, Causes, Controls, (New Jersey: Prentice Hall, 2003)

Khan, L. Ali, Phenomenology of International Terrorism: Understanding Islamic Militancy, (Leiden: Martinus Nijhoff Publisher, 2006)

Laqueur, Walter, The New Terrorism: Fanaticism and the Arms of Mass Destruction, (New York: Oxford University Press, 1999)

Lesser, Ian, et al., Countering the New Terrorism, (Santa Monica, CA: Rand Corporation Publications, 1999)

Lewis, Bernard, 'The Roots of Muslim Rage', Atlantic Monthly, 266: 3 (1990)

Malik, Habib, "Political Islam and the Roots of Violence", in Elliott Abrams (ed.), The Influence of Faith: Religious Groups and U.S. Foreign Policy, (Lanham, MD: Rowman \& Littlefield, 2001)

Martin, Gus, Understanding Terrorism: Challenges, Perspectives, and Issues, (London: Sage, 2003)

Mendelsohn, Barak, "Sovereignty Under Attack: The International Society Meets the Al Qaeda Network", Review of International Studies, 31 (2005)

Miliken, Jennifer, "The Study of Discourse in International Relations: A Critique of Research and Methods", European Journal of International Relations, 5:2, (1999)

Mishal, Shaul, and Rosenthal, Maoz, "Al Qaeda as a Dune Organization: Towards a Typology of Islamic Terrorist Organizations", Studies in Conflict \& Terrorism, 28 (2005)

NS interview, "Patricia Hewitt", Newstatesman, 25 July 2005, hal. 26.

Paz, Reuven, “Is There an 'Islamic Terrorism'?”, International Policy Institute for Counter-Terrorism (ICT) Publication, Herzilya, Israel, 7 September 1998, at http://www.ict.org.il/articles/articledet.cfm?articled=46, diakses pada tanggal 05 Desember 2012,

Paz, Reuven, "Radical Islamist Terrorism: Points for Pondering”, International Policy Institute for Counter-Terrorism (ICT) Publication, Herzilya, Israel, 20 June 2001, at http://www.ict.org.il/articles/articledet.cfm?articleid=367, diakses tanggal 05 Desember 2012

Pillar, Paul, "Terrorism Goes Global: Extremist Groups Extend their Reach Worldwide", Brookings Review, 19: 4 (2001)

Pipes, Daniel, “Who is the Enemy?”, Commentary, 113: 1 ( January 2002), http://www.danielpipes.org/article/103, diakses pada tanggal 05 Desember 2012

Poole, Elizabeth and Richardson, John, Muslims and the News Media, (London: I.B. Tauris, 2006) 
Ranstorp, Magnus, 'Terrorism in the Name of Religion', Journal of International Affairs, 50: 1 (1996)

Rapoport, David, 'Fear and Trembling: Terrorism in Three Religious Traditions', American Political Science Review, 78: 3 (1984)

Richardson, John, (Mis)Representing Islam: The Racism and Rhetoric of British Broadsheet Newspapers, (Amsterdam: John Benjamins, 2004)

Sadowsky, Yahya, 'The New Orientalism and the Democracy Debate', dalam Joel Beinin and Joe Stork (eds), Political Islam, (Berkeley, CA: University of California Press, 1996).

Sageman, Marc, Understanding Terror Networks, (Philadelphia: University of Pennsylvania Press, 2004), hal. 1.

Said, Edward, Covering Islam: How the Media and the Experts Determine How We See the Rest of the World, (London: Vintage, 1981), revised edition 1997

Schbley, Ayla, "Religious Terrorism, the Media, and International Islamization Terrorism: Justifying the Unjustifiable", Studies in Conflict \& Terrorism, 27 (2004)

Sheehan, Jack, Reel Bad Arabs: How Hollywood Vilifies a People, (Northampton, MA: Interlink Publishing Group, 2004)

Shugart II, William F., “An Analytycal History of Terrorism: 1945-2000”, Public Choice, vol. 128, (2006)

Stern, Jessica, Terror in the Name of God: Why Religious Militants Kill, (New York: HarperCollins, 2003)

Takeyh, Ray, and Gvosdev, Nikolas, 'Radical Islam: The Death of an Ideology?', Middle East Policy, 11: 4 (2004),

The 9/11 Commission, Final Report of the National Commission on Terrorist Attacks Upon the United States, (New York: W. W. Norton \& Co., 2004)

UK Foreign and Commonwealth Office/Home Office, "Draft Report on YoungMuslims and Extremism", April 2004, dapat ditemukan di http:// www.globalsecurity.org/security/library/report/2004/muslimext-uk. htm, diakses tanggal 05 Desember 2012

US Department of State, "Significant Terrorist Incidents, 1961-2003: A Brief Chronology", at http://www.state.gov/r/pa/ho/pubs/fs/5902pf.htm.

Wiktorowicz, Quintan, "A Genealogy of Radical Islam", Studies in Conflict \&Terrorism, 28 (2005) 